\title{
HELIUM IN GROUNDWATERS OF THE ALTAI REPUBLIC
}

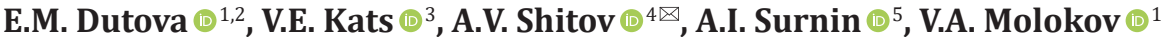

${ }^{1}$ Tomsk Polytechnic University, 30 Lenin Ave, Tomsk 634050, Russia

${ }^{2}$ Tomsk State University, 36 Lenin Ave, Tomsk 634050, Russia

${ }^{3}$ OJSC Geological Enterprise Altai-Geo, 52 Zavodskaya St, Maima 649100, Republic of Altai, Russia

${ }^{4}$ Gorno-Altaisk State University, 1 Lenkin St, Gorno-Altaisk 649000, Republic of Altai, Russia

${ }^{5}$ Siberian Research Institute of Geology, Geophysics and Mineral Resources, 67 Krasny Ave, Novosibirsk 630091, Russia

ABSTRACT. This study of groundwaters of the Altai Republic is relevant due to the need to identify earthquake precursors in seismically active zones of the study area. Chemical composition of groundwater is widely known as an indicator of seismic processes, which changes in future earthquake focal zones. In this regard, studying helium contents in groundwater is of particular importance - anomalous concentrations of helium are typical of fault zones, and helium concentration variations in time can be referred to as earthquake precursors.

Our study was focused on the distribution of helium in groundwaters of the Altai Republic and aimed to determine and justify positioning of permanent monitoring sites for investigation of earthquake precursors.

During the field study, groundwater samples were taken from wells and springs located within the area covered by the established state monitoring network (GONS). Groundwater aquifers and water-bearing zones from Quaternary to Proterozoic ages were sampled.

Analysis of the groundwater samples shows spatial variations of helium concentration in the study area. Water samples from fault zones have increased concentrations of helium. The concentration of helium is high in the groundwater from the Chuya artesian basin, i.e. near the epicentral zone of the M 7.5 Altai (Chuya) earthquake of September 27, 2003.

KEYWORDS: groundwater; monitoring; spring; water well; hydrogeochemical characteristics; helium; fault zone; earthquake

\section{RESEARCH ARTICLE}

Correspondence: Alexander V. Shitov, sav103@yandex.ru
Received: May 26, 2019

Revised: February 27, 2020

Accepted: March 11, 2020

FOR CITATION: Dutova E.M., Kats V.E., Shitov A.V., Surnin A.I., Molokov V.A., 2020. Helium in groundwaters of the Altai Republic. Geodynamics \& Tectonophysics 11 (3), 651-663. doi:10.5800/GT-2020-11-3-0497 


\title{
ГЕЛИЙ В ПОДЗЕМНЫХ ВОДАХ РЕСПУБЛИКИ АЛТАЙ
}

\author{
Е.М. Дутова ${ }^{1,2}$, В.Е. Кац ${ }^{3}$, А.В. Шитов ${ }^{4}$, А.И. Сурнин ${ }^{5}$, В.А. Молоков ${ }^{1}$
}

${ }^{1}$ Томский политехнический университет, 634050, Томск, пр-т Ленина, 30, Россия

${ }^{2}$ Томский государственный университет, 634050, Томск, пр-т Ленина, 36, Россия

${ }^{3}$ ОАО «Геологическое предприятие «Алтай-Гео», 649100, Майма, ул. Заводская, 52, Респ. Алтай, Россия

${ }^{4}$ Горно-Алтайский государственный университет, 649000, Горно-Алтайск, ул. Ленкина, 1, Респ. Алтай, Россия

${ }^{5}$ Сибирский научно-исследовательский институт геологии, геофизики и минерального сырья, 630091, Новосибирск, Красный пр-т, 67, Россия

АНнотАЦИЯ. Актуальность исследований определяется необходимостью обоснования предвестников землетрясений в сейсмоактивных районах Республики Алтай. Широко известно, что химический состав подземных вод является индикатором сейсмических процессов, отмечены его изменения в зонах очагов предстоящих землетрясений. Изучение содержаний гелия в подземных водах в этой связи имеет особое значение, так как аномальные величины этого газа являются показателем вод в зонах разрывных нарушений, а его временные вариации могут быть использованы в качестве предвестника землетрясений.

Цель работы - изучить распределение гелия в подземных водах Республики Алтай в связи с поисками и обоснованием постоянно действующих пунктов наблюдений, являющихся базой для поиска предвестников сильных сейсмических событий.

В основу работы положены результаты опробования подземных вод на территории Республики Алтай. Пунктами опробования являлись скважины и родники действующей в республике государственной наблюдательной сети. При полевых исследованиях опробованы разнообразные водоносные комплексы и водоносные зоны от четвертичного до протерозойского возраста.

По материалам проведенных исследований установлены пространственные изменения содержания гелия в подземных водах на территории Республики Алтай; предполагается приуроченность повышенных значений концентраций гелия к разломным зонам. Выявлено высокое содержание гелия в подземных водах Чуйского артезианского бассейна, вблизи эпицентральной зоны Алтайского (Чуйского) землетрясения (27.09.2003 г., магнитуда 7.5).

КЛЮЧЕВЫЕ СЛОВА: подземные воды; мониторинг подземных вод; родник; скважина; гидрогеохимические характеристики; гелий; зона разрывных нарушений; землетрясение

\section{1. ВВЕДЕНИЕ}

Республика Алтай (РА) находится в центральной части Евразийского континента в пределах Алтае-Саянской складчатой области. На современном этапе геологического развития территория РА представляет собой мозаичную, чешуйчато-блоковую структуру, сформированную в результате процессов горообразования, характеризующуюся слабодифференцированными положительными вертикальными движениями [Turkin, Fedak, 2008]. Основными положительными структурами с наибольшей интенсивностью деформаций являются Катунское, Тигирекско-Теректинское, Бащелакское, Ануйское, Сумультинско-Курайское, Западно-Саянское глыбово-сводовые поднятия, связанные с крупнейшими разломами - Курайским, Кадринским, Тигирекским, Теректинским, Бащелакским, Ташантинским. Названные структуры на отдельных участках характеризуются значительными величинами суммарных амплитуд вертикальных движений, порядка 2000-3000 м за неоген-четвертичное время [Bogachkin, 1981]. Среди поднятий располагаются межгорные котловины (Чуйская, Курайская, Уймонская, Бертекская, Джулукульская, Канская и другие, более мелкие). Все они имеют в целом небольшие размеры и сложены неоген-четвертичными и четвертичными отложениями мощностью от первых сотен метров до 1000 м (Чуйская впадина). В фундаменте котловин зачастую картируются тектонические зоны крупных долгоживущих разломов. Так, например, Чуйская котловина располагается в зоне сочленения Чарышско-Теректинского, Южно-Теректинского и Баратальского глубинных разломов и оперяющихся нарушений.

По данным Алтае-Саянского филиала Федерального исследовательского центра Единой геофизической службы РАН, с начала 2000-х гг. была зафиксирована сейсмическая активизация изучаемой территории [Gol'din et al., 2004]. Самое сильное из последних землетрясений (Чуйское) с магнитудой 7.5 балла произошло на территории РА 27 сентября 2003 г. в высокогорном КошАгачском районе (рис. 1). Землетрясение нанесло существенный, более двух миллиардов рублей, экономический ущерб.

Многими исследователями установлено, что подземные воды являются индикатором сейсмических событий [Biagi et al., 2006; Chen et al., 2013; Fidani et al., 2017; Lopatin, Semenov, 2018; Semenov et al., 2018; Seminsky, Tugarina, 2011; Wang, Manga, 2010; Vartanyan, 1979, 2019; Kissin, 1982, 2009; Semenov et al., 2010, 2015; 
Seminsky K.Z., Seminsky A.K, 2016; Utkin, Yurkov, 1997; Yanitskij, 1979]. После Чуйского землетрясения активизировались изыскания по поиску предвестников землетрясений на Алтае.

\section{2. ГИДРОГЕОЛОГИЧЕСКИЕ УСЛОВИЯ РАЙОНА ИССЛЕДОВАНИЙ}

Территория РА входит в состав Алтае-Саянской горной области. Большую часть территории (85 \%) занимают горно-складчатые сооружения с массивами трещинных вод (рис. 2). Существенно меньшую часть (15 \%) занимают артезианские бассейны (Чуйский, Уймонский, Бертекский, Курайский и Джулукульский). В условиях гидрогеологических массивов подземные воды приурочены к трещинным, трещинно-жильным, трещинно-карстовым и карстовым коллекторам в осадочных, вулканогенных, метаморфических и интрузивных породах широкого возрастного диапазона - от мезозойского до протерозойского. В условиях чехла артезианских бассейнов подземные воды сосредоточены в порово-пластовых коллекторах четвертичных, неогеновых и палеогеновых отложений (рис. 2). В зонах контактов массивов и бассейнов в фундаменте артезианских бассейнов широкое распространение имеют воды зон тектонических нарушений, характеризующиеся глубокой циркуляцией (рис. 2) и зачастую контролируемые родниковой разгрузкой (рис. 3).
Особенности геохимии подземных вод Горного Алтая, как и большинства горно-складчатых сооружений, в целом подчиняются высотным ландшафтно-климатическим условиям [Shvartsev, 1998; Shvartsev, Dutova, 2001; Dutova, 2000, 2003, 2005; Dutova et al., 2006, 2015, 2017]. Обобщенные сведения о составе подземных вод приведены в табл. 1.

В высокогорных районах с горно-луговыми, гольцовыми ландшафтами формируются ультрапресные подземные воды с низкой минерализацией, гидрокарбонатным натриево-кальциевым составом, слабокислым характером среды. Подземные воды зоны таежных лесов, расположенной гипсометрически ниже, в большинстве своем умеренно пресные, гидрокарбонатные кальциево-магниевые, слабощелочные.

Подземные воды лесостепных и степных ландшафтов становятся собственно пресными с общей минерализацией до 1 г/л, а иногда и более, по составу сульфатногидрокарбонатными, хлоридно-гидрокарбонатными, кальциево-магниево-натриевыми. В условиях степных ландшафтов межгорных впадин (Чуйский и Уймонский артезианские бассейны) зачастую появляются локально распространенные солоноватые сульфатно-(хлоридно)-гидрокарбонатные натриевые и хлоридные кальциево-магниевые воды.

По данным мониторинговых исследований в период до активизации сейсмической деятельности, состав

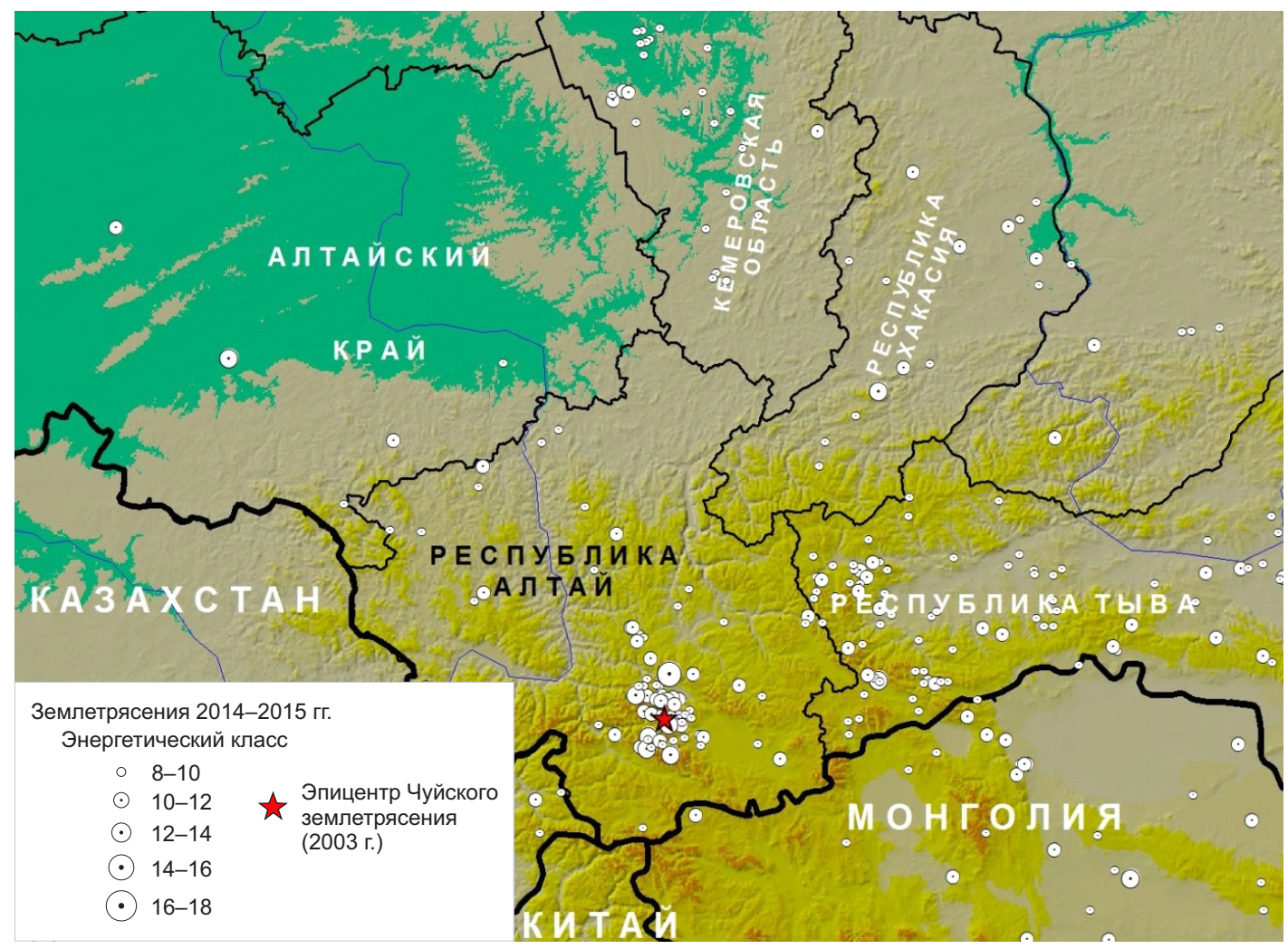

Рис. 1. Местоположение эпицентра землетрясения 27.09.2003 г., М 7.5, энергетический класс и эпицентры землетрясений 2014-2015 гг.

Fig. 1. The epicentral zone of the M 7.5 Altai (Chuya) earthquake of 27 September 2003. Energy class and earthquake epicenters of 2014-2015. 
подземных вод в республике характеризовался минимальными вариациями режимных показателей и контролировался преимущественно сезонными факторами.

В период активизации сейсмических событий и после них гидродинамический, геотемпературный режим и химический состав подземных вод в Алтае-Саянском регионе (АСР) в целом и в Республике Алтай в частности заметно изменились [Kats et al., 2009, 2010; Shitov et al., 2016].

В целом, в форшоковый период (перед Чуйским землетрясением) установлены факты понижения уровня

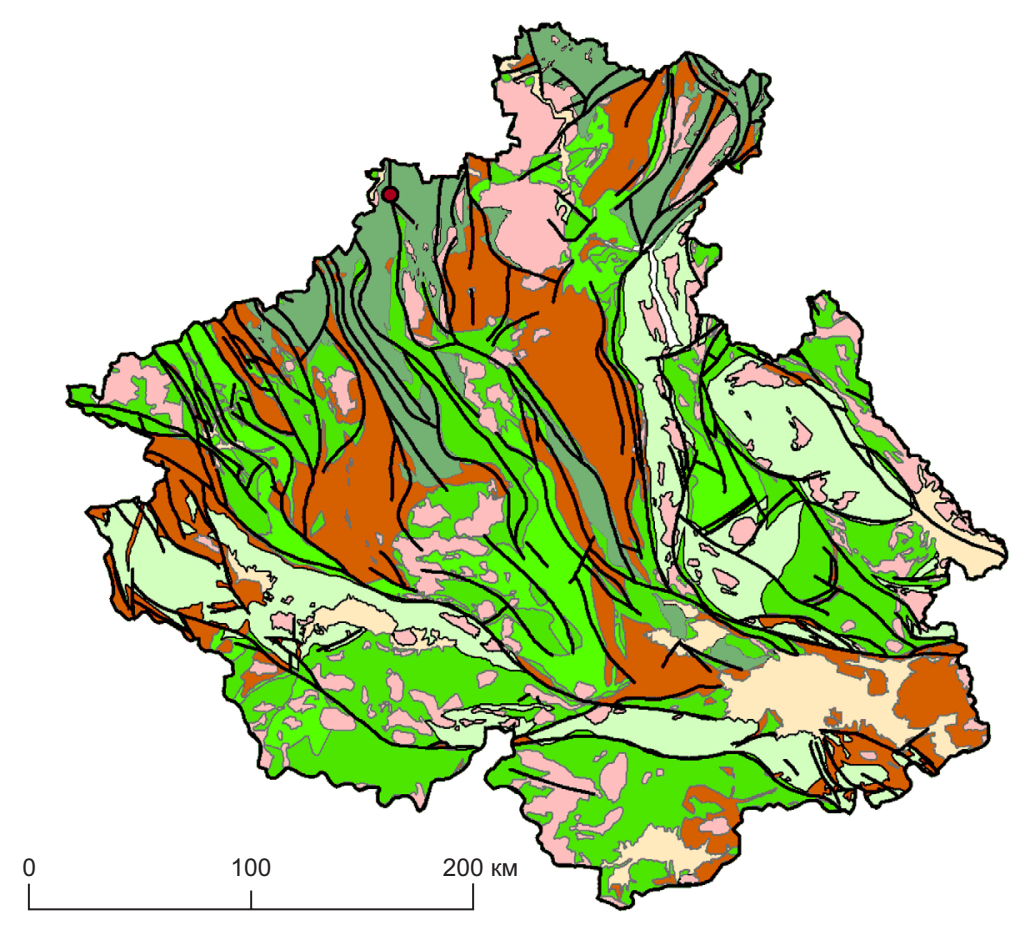

Основные водоносные комплексы

Водоносная зона венд-кембрийских пород

Водоносная зона кембрийских и кемброордовикских пород

Водоносная зона ордовикско-силурийских пород

Водоносная и относительно водоносная зона девонских отложений

Водоносная и относительно водоносная нижнепалеозойская зона

Водоносный комплекс голоценовых и плейстоценовых отложений

Относительно водоносная зона интрузивных образований

Зоны разрывных нарушений

Рис. 2. Гидрогеологическая карта Республики Алтай.

Fig. 2. Hydrogeological map of the Altai Republic.

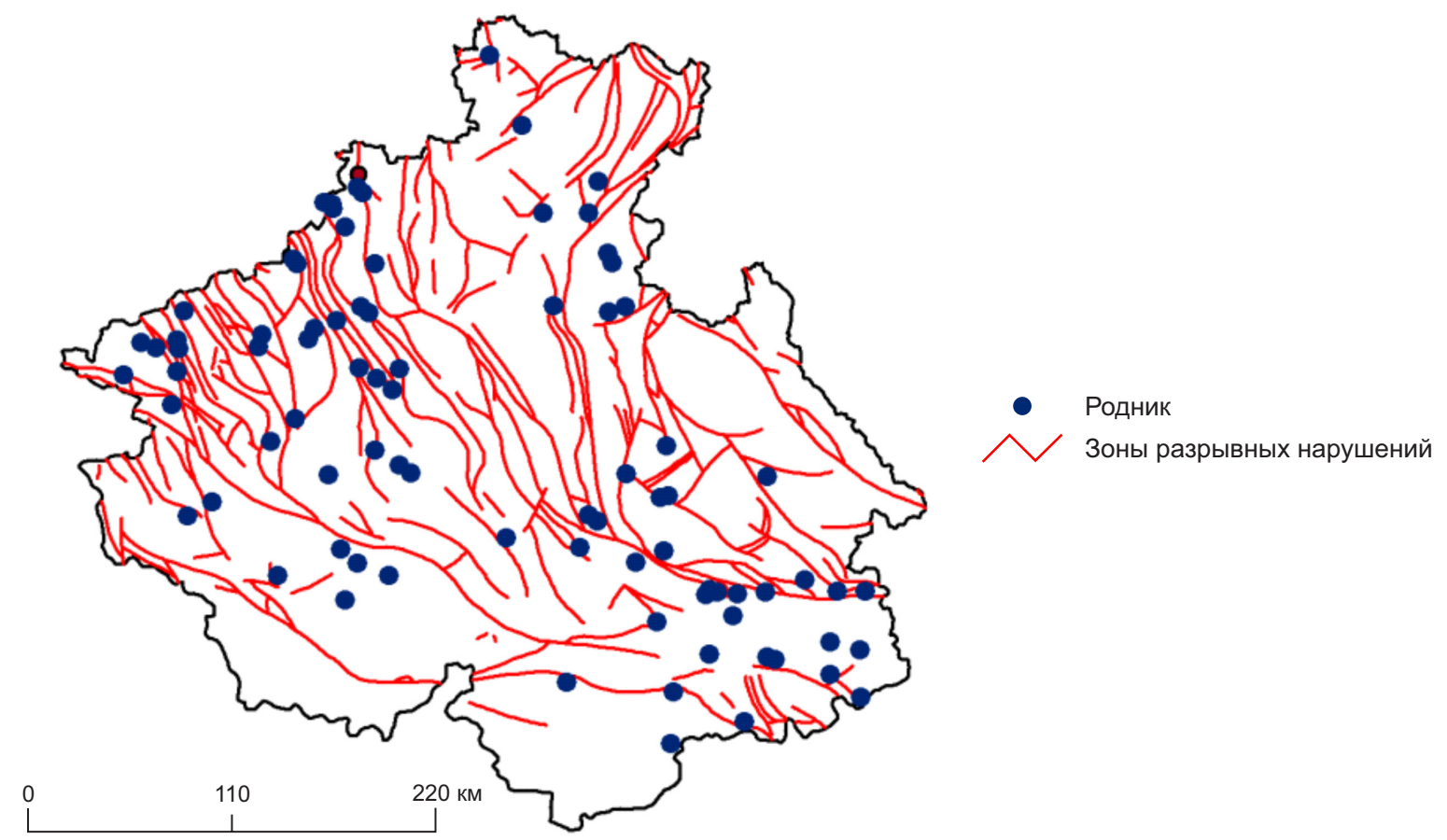

Рис. 3. Распределение родников на территории Республики Алтай.

Fig. 3. Locations of springs, Altai Republic. 
Таблица 1. Средний химический состав подземных вод Горного Алтая, мг/л

Table 1. Average chemical composition of groundwaters of the Altai Mountains, mg/l

\begin{tabular}{|c|c|c|c|c|c|}
\hline \multirow[b]{2}{*}{ Компоненты } & \multicolumn{5}{|c|}{ Ландшафты } \\
\hline & горно-луговой* & горно-таежный* & $\begin{array}{c}\text { горно-таежный, гор- } \\
\text { но-лесостепной** }\end{array}$ & $\begin{array}{c}\text { степной межгорных } \\
\text { впадин** }\end{array}$ & среднее** \\
\hline $\mathrm{pH}$ & 6.9 & 7.6 & 7.7 & 7.6 & 7.4 \\
\hline $\mathrm{HCO}_{3}^{-}$ & 73.0 & 248.0 & 279.0 & 246.0 & 218.0 \\
\hline $\mathrm{Cl}^{-}$ & 3.6 & 5.1 & 19.1 & 43.7 & 17.0 \\
\hline $\mathrm{SO}_{4}^{2-}$ & 2.8 & 12.1 & 15.0 & 60.1 & 19.7 \\
\hline $\mathrm{Ca}^{2+}$ & 13.9 & 54.7 & 68.0 & 39.9 & 48.0 \\
\hline $\mathrm{Na}^{+}$ & 5.9 & 12.1 & 22.1 & 72.1 & 21.2 \\
\hline $\mathrm{Mg}^{2+}$ & 5.4 & 15.6 & 15.2 & 15.31 & 15.3 \\
\hline $\mathrm{K}^{+}$ & 1.15 & 1.26 & 1.92 & 4.59 & 1.48 \\
\hline $\mathrm{SiO}_{2}$ & 9.6 & 11.4 & 15.8 & 15.8 & 11.4 \\
\hline Сумма & 104.0 & 364.0 & 420.0 & 530.0 & 352.0 \\
\hline Число анализов & 122 & 338 & 280 & 44 & 930 \\
\hline
\end{tabular}

Примечание. * - по [Shvartsev, 1998]; ** - по [Dutova, 2005] с использованием данных АО «Алтай-Гео».

Note. * - after [Shvartsev, 1998]; ** - after [Dutova, 2005], using the data of JSC Altai-Geo.

подземных вод, а в момент сейсмического события подъем. Так, в районе с. Мараловодка был установлен факт резкого понижения уровня воды на 1.5 м в августе 2003 г. В момент основного события в районе с. Старый Бельтир (эпицентр землетрясения) отмечался резкий подъем уровня подземных вод и в некоторых скважинах наблюдались самоизливы в виде двухметровых фонтанов.

В г. Горно-Алтайске в частной индивидуальной колонке установлен факт резкого подъема температуры воды до $48^{\circ}$. Замечены изменения в ионно-солевом составе подземных вод, рост величины рН, общей минерализации, натрия, сульфатов, хлоридов, фтора.

После основного Чуйского землетрясения, в период малоамплитудных афтершоковых событий, которые продолжаются до настоящего времени, установлены существенные вариации объемной активности радона в подземных водах [Kats et al., 2009]. В период сейсмических событий объемная активность радона в подземных водах существенно увеличивается по сравнению с фоновой. Рост значений активности радона в воде устанавливался за неделю до сейсмического события и продолжался в течение десяти дней.

Количество радона в подземных водах зависит от интенсивности сейсмического события и гидрогеологических особенностей разреза. Аномальные значения объемной активности радона в подземных водах в большинстве случаев наблюдались в скважинах, находящихся на больших расстояниях от эпицентров землетрясений, в так называемой «дальней» зоне [Utkin, Yurkov, 1997]. В эпицентральных участках землетрясений объемная активность радона в подземных водах, как правило, минимальная.

Так, например, на водозаборах г. Горно-Алтайска, эксплуатирующих венд-нижнекембрийскую водоносную зону карбонатно-терригенных пород, располагающихся в Катунской сейсмоактивной зоне, в зоне крупного Катунского глубинного разлома аномальная объемная активность радона (до 2650 Бк/л) была зафиксирована в период слабых сейсмических событий (3-4 балла), эпицентры которых находились в 250-360 км от водозаборов. Подобные закономерности отмечались и в других сейсмически активных зонах [Kopylova, Voropaev, 2005; Semenov et al., 2010].

Данная работа продолжает исследования по поиску гидрогеологических, гидрогеохимических предвестников землетрясений Горного Алтая. Ее целью является изучение распределения гелия в подземных водах Республики Алтай в связи с поисками и обоснованием постоянно действующих пунктов наблюдений за предвестниками землетрясений. Изучение содержаний гелия в подземных водах в этой связи имеет особое значение, так как этот газ в аномальных величинах является показателем зон разрывных нарушений, а его временные вариации могут быть использованы в качестве предвестника землетрясений [Sano et al., 2016; Semenov et al., 2010; Wang, Manga, 2010].

\section{3. МЕТОДИКА РАБОТ}

Опробование водных объектов для определения в них гелия проводилось сотрудниками ТЦ «Алтайгеомониторинг», являющегося структурным подразделением ОАО «Алтай-Гео», и сотрудниками Томского политехнического университета. Пунктами наблюдений являлись скважины и родники. В 2014 г. было отобрано 47 проб, в том числе 37 из родников и 9 из скважин. В 2015 г. было отобрано 39 проб, в том числе 23 из родников и 15 из скважин (рис. 4).

При полевых исследованиях пробы подземных вод отбирались из водоносных комплексов и зон широкого 
возрастного диапазона, от неогенового до протерозойского. Значительная часть пунктов была опробована дважды.

Аналитические работы по определению гелия выполнялись по стандартной методике на приборе ИНГЕМ-1 [Yanitskij, 1979; Eremeev, 1991] в лаборатории гидрогеологии нефтегазоносных провинций Сибирского научно-исследовательского института геологии, геофизики и минерального сырья (г. Новосибирск).

Условия опыта: $\mathrm{T}=20^{\circ} \mathrm{C}, \mathrm{P}=750$ мм рт.ст.
Расчет превышений содержания водорастворенного гелия в изученных пробах $(\Delta \mathrm{He}, \%$ об.) над атмосферным фоном поверхностных вод производился по формуле:

$$
\Delta \mathrm{He}=\mathrm{C} \cdot \mathrm{R} \cdot \Delta \mathrm{J}
$$

где C = 0.000409 \% - цена деления индикатора ИНГЕМ (по газу), $\mathrm{R}=0.0088$ - растворимость Не в воде при $20{ }^{\circ} \mathrm{C}, \Delta \mathrm{J}-$ приращение сигнала индикатора при анализе пробы.

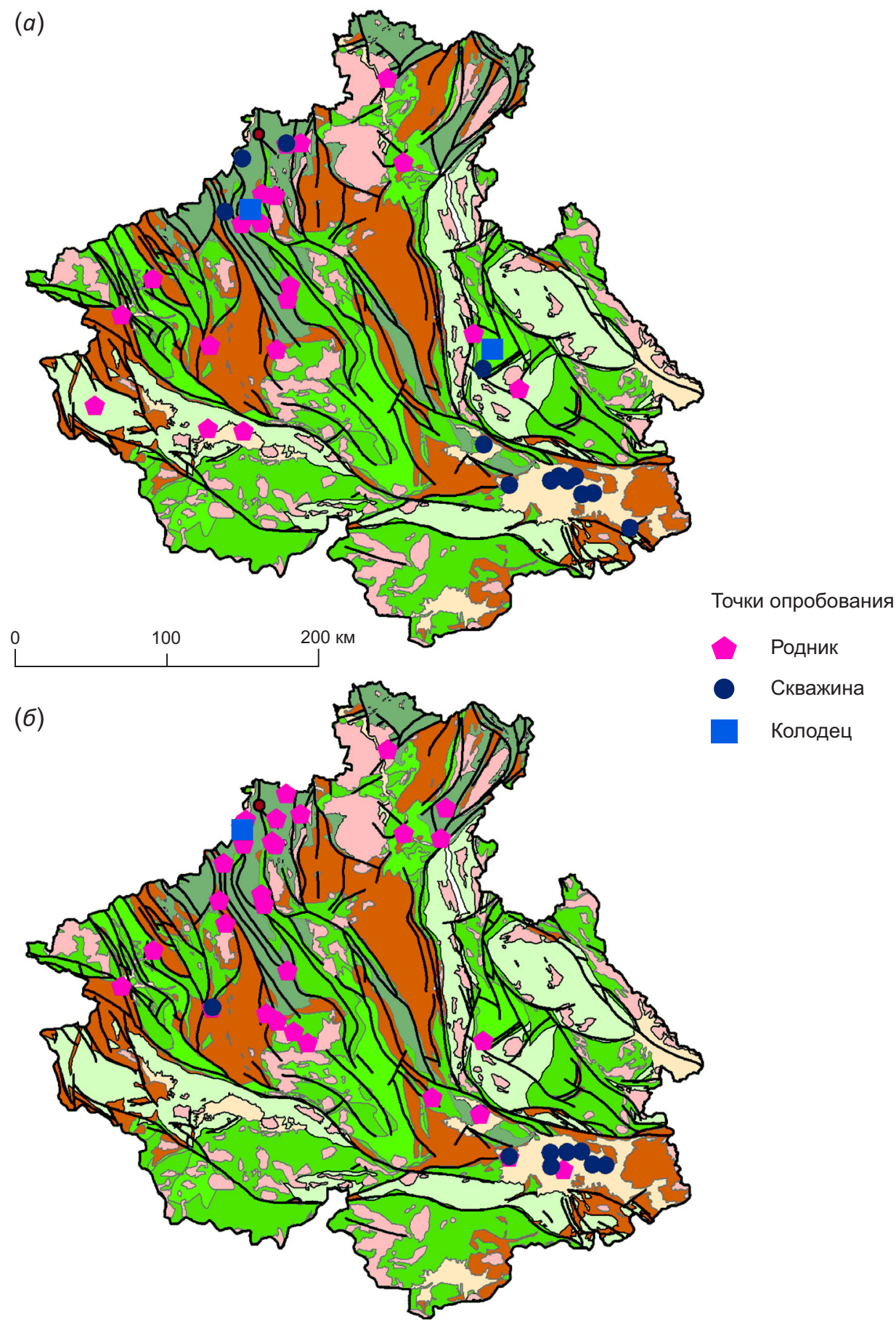

Рис. 4. Схемы отбора проб на содержание гелия в подземных водах: (a) - 2015 г.; (б) - 2014 г.

Fig. 4. Schematic maps showing groundwater sampling sites for helium concentration analysis in 2015 (a) and 2014(б). 
Абсолютные содержания водорастворенного гелия (\% об.) в пробах с учетом атмосферного фона рассчитаны по формуле:

$$
\text { He абс. }=\Delta \mathrm{He}+0.00052 \cdot \mathrm{R},
$$

где 0.00052 \% об. - фоновое содержание гелия в атмосферном воздухе; $0.00052 \cdot \mathrm{R}=0.000004576$ \% об. - фоновое (атмосферное) содержание растворенного гелия в поверхностных водах.

\section{4. РЕЗУЛЬТАТЫ ИССЛЕДОВАНИЙ РАСПРЕДЕЛЕНИЯ ГЕЛИЯ В ПОДЗЕМНЫХ ВОДАХ}

Содержание гелия в подземных водах РА изменяется от 0.000001 до $0.004295 \%$ об., в среднем равно 0.000145 \% об. Более высокие концентрации гелия характерны для вод зоны интрузивных образований, как правило, отличающихся повышенной радиоактивностью. Наиболее высокие максимальные и средние содержания гелия характерны для подземных вод комплекса голоценовых и плейстоценовых отложений Чуйского артезианского бассейна (табл. 2).

Для большинства опробованных водопунктов (64\%) характерны фоновые или околофоновые (т.е. превышение по сравнению с атмосферным фоном менее двух раз или менее 0.000009 \% об.) абсолютные содержания гелия (табл. 3). Общее распределение содержаний гелия по двум годам было примерно одинаковым. Встречаемость же содержаний гелия, превышающих фон в сотни раз, в 2014 г. была почти в три раза выше по сравнению с 2015 г.
Анализ пространственного распределения содержаний гелия в подземных водах РА показал, что большая часть объектов с его повышенными значениями тяготеет к тектоническим зонам и к оперяющим их разломам (рис. 5).

Наиболее высокие содержания гелия (в десятки и сотни раз превышающие фоновые) выявлены в подземных водах Чуйского артезианского бассейна, в эпицентральной зоне Алтайского (Чуйского) землетрясения (рис. 5). Подобные содержания в разное время определялись в тектонически активных зонах соседних, аналогичного типа, структурах АСР [Badminov et al., 2013, 2017; Rychkova et al., 2017].

Как отмечалось выше, Чуйский бассейн в тектоническом плане находится в зоне сочленения глубинных разломов. Предполагается, что эти структуры были заложены в среднем рифее как линейные проницаемые зоны. Впоследствии в их пределах на различных этапах геологического развития наиболее интенсивно проявлялись тектонические и магматические процессы. В течение длительного времени в пределах зон глубинных разломов образовалась система субмеридиональных и субширотных разрывов 2-го порядка, что привело к образованию линейно-блокового строения этих структур. Широкое распространение получили в пределах шовных зон продукты магматической деятельности, представленные эффузивными и интрузивными образованиями.

До настоящего времени в период малоамплитудных сейсмических событий после основного Чуйского

Таблица 2. Содержание гелия в подземных водах РА, \% об.

Table 2. Helium concentration in groundwaters of the Altai Republic, \% vol.

\begin{tabular}{|c|c|c|c|c|}
\hline \multirow{2}{*}{ Водоносные подразделения } & \multirow{2}{*}{$\begin{array}{c}\text { Количество } \\
\text { значений }\end{array}$} & \multicolumn{3}{|c|}{ Содержание гелия } \\
\hline & & Минимальное & Максимальное & Среднее \\
\hline $\begin{array}{l}\text { Водоносный комплекс голоценовых и плейстоце- } \\
\text { новых отложений (Q-N) }\end{array}$ & 23 & 0.000005 & 0.00430 & 0.000466 \\
\hline $\begin{array}{l}\text { Водоносная и относительно водоносная зона } \\
\text { девонских отложений (D) }\end{array}$ & 10 & 0.000004 & 0.00001 & 0.000005 \\
\hline $\begin{array}{l}\text { Водоносная зона ордовикско-силурийских пород } \\
(\mathrm{O}-\mathrm{S})\end{array}$ & 9 & 0.000001 & 0.00010 & 0.000018 \\
\hline $\begin{array}{l}\text { Водоносная зона кембрийских и кембро-ордовик- } \\
\text { ских пород }(€, €-0)\end{array}$ & 11 & 0.000002 & 0.00002 & 0.000006 \\
\hline Водоносная зона венд-кембрийских пород (V) & 22 & 0.000004 & 0.00008 & 0.000013 \\
\hline $\begin{array}{l}\text { Относительно водоносная зона интрузивных } \\
\text { образований (vPz) }\end{array}$ & 6 & 0.000002 & 0.00095 & 0.000171 \\
\hline Все водоносные подразделения & 85 & 0.000001 & 0.00430 & 0.000145 \\
\hline
\end{tabular}

Таблица 3. Распределение содержаний гелия (в единицах фона), \%

Table 3. Helium content distribution (background values), \%

\begin{tabular}{lcccc}
\hline \multirow{2}{*}{ Год отбора } & \multicolumn{3}{c}{ Содержание гелия (в единицах фона) } \\
\cline { 2 - 5 } & $<2$ & $>2$ & $>3$ & 30 \\
2014 & 64 & 36 & 3100 & 20 \\
2015 & 64 & 36 & 31 & 20 \\
\hline
\end{tabular}



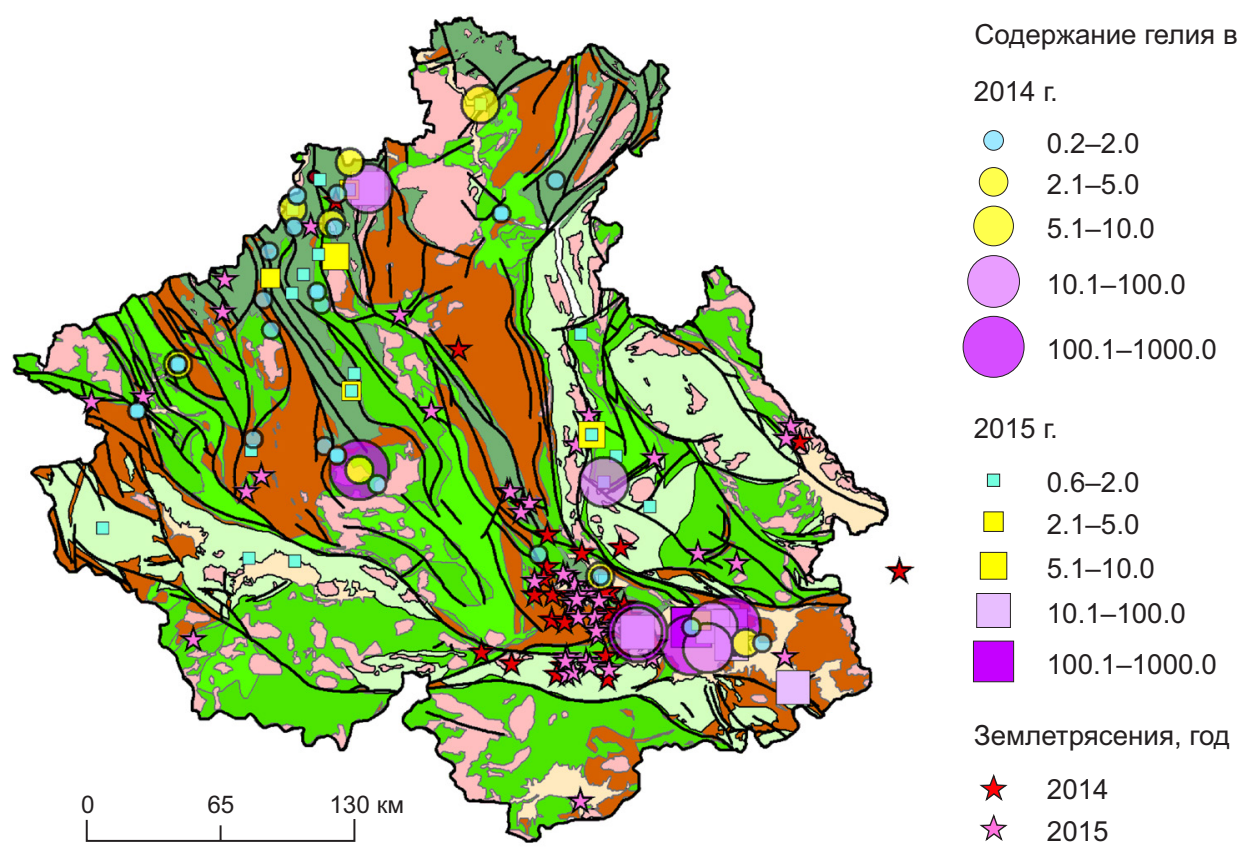

Рис. 5. Распределение гелия в подземных водах Республики Алтай.

Fig. 5. Helium distribution in groundwaters of the Altai Republic.

землетрясения в подземных водах Чуйского бассейна фиксируются аномальные повышения величины $\mathrm{pH}$, мутности, концентраций сульфатов, хлоридов магния, натрия, аммония, лития, мышьяка, марганца [Shitov et al., 2008, 2016; Kats et al., 2010]. Ниже, на рис. 6, приведена динамика многолетних изменений ряда таких гидрогеохимических показателей, как мутность, $\mathrm{pH}_{\text {, }} \mathrm{SO}_{4}{ }^{2-}$, $\mathrm{Mg}^{2+}$ для наблюдательного пункта с. Кош-Агач, и показателей сейсмической активности.

В табл. 4 приведена характеристика химического состава опробованных водных объектов РА, где были обнаружены повышенные содержания гелия.

Практически для всех этих водных объектов характерны существенные вариации показателей гидродинамического и температурного режима, а также гидрогеохимических характеристик.

Ниже приводится характеристика химического состава одного из объектов такого типа - родника Караташ (вблизи с. Тебелер) (табл. 5).

Как видно из табл. 5, отмечаются существенные вариации в концентрациях макрокомпонентов в источнике. Проба, отобранная в сентябре 2014 г., когда в Кош-Агачском районе было зафиксировано шесть сейсмических событий с магнитудой до 3.8 , характеризуется существенным подкислением среды и наиболее высокими концентрациями большинства показателей (натрия, сульфатов, хлоридов, минерализации). Такие явления, вероятно, обусловлены активизацией миграции газонасыщенных флюидов по зонам разрывных нарушений в период сейсмических событий, приводящих к повышению агрессивности и растворяющей способности подземных вод. Приуроченность данного родника к зоне Чуйского глубинного разлома была подтверждена и ранее проведенными геолого-съемочными и гидрогеологическими работами.

Мы связываем вариации в концентрациях с сейсмическими событиями. Во-первых, зоны разломов находятся в состоянии постоянного напряжения (с 2003 г.), во-вторых, после каждого «толчка» (а их устанавливается не менее 500-700 в АСР в течение года) в разломной зоне, вероятно, открываются новые локальные трещины, по которым происходит восходящая миграция газовой фазы. Этот процесс может продолжаться достаточно длительно.

Проведенное гелиеметрическое опробование позволяет рекомендовать наиболее информативные пункты для наблюдений за концентрациями гелия в подземных водах РА. Вероятно, временные изменения гелия в дальнейшем могут использоваться в качестве краткосрочного предвестника землетрясений [Semenov et al., 2015, 2017].

В 2006-2008 г. для реализации Международного проекта по ведению совместного ГГД мониторинга РФ и стран СНГ (объект «Организация и проведение гидрогеодинамического мониторинга по изучению сейсмогеодинамического состояния геологической среды территорий РФ, сопредельных со странами СНГ») была создана специализированная региональная наблюдательная сеть. Три наблюдательных пункта этой сети созданы в Республике Алтай. Это скважины в селах Кызыл-Таш (Курай), Турочак и Баштала (Усть-Кокса).

Наблюдательные пункты функционируют с 2006 г. по настоящее время. На всех скважинах ежечасно проводятся измерения уровня, температуры атмосферного давления, электропроводимости подземных вод. Газогидрогеохимический мониторинг на наблюдательных 


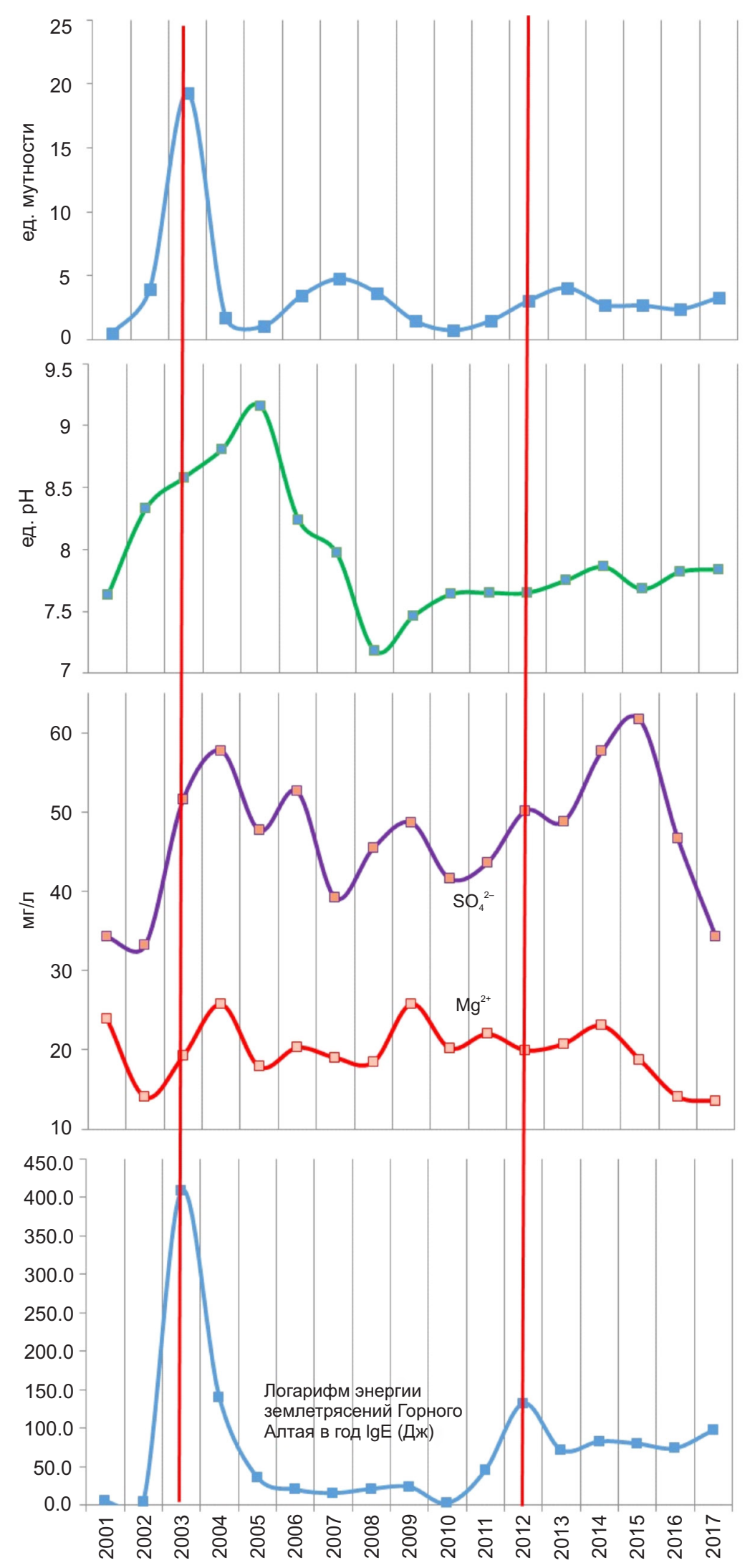

Рис. 6. Динамика многолетних изменений ряда гидрогеохимических показателей (мутность, $\mathrm{pH} \mathrm{SO}_{4}^{2-}, \mathrm{Mg}^{2+}$ ) для наблюдательного пункта с. Кош-Агач и показателей сейсмической активности на территории Горного Алтая (вертикальными линиями показаны: Чуйское землетрясение 2003 г., Тувинское землетрясение 2012 г.).

Fig.6. Dynamics of long-term changes in hydrogeochemical parameters and seismic activity indicators in the Altai Mountains. Parameters: water turbidity, $\mathrm{pH}, \mathrm{SO}_{4}{ }^{2-}$, and $\mathrm{Mg}^{2+}$ (data from the Kosh-Agach monitoring site). Vertical lines mark Chuya (2003) and Tuva (2012) earthquakes. 
Таблица 4. Химический состав подземных вод (мг/л), в которых обнаружены повышенные содержания гелия

Table 4. Chemical composition of groundwaters (mg/l) with increased helium contents

\begin{tabular}{|c|c|c|c|c|c|c|c|c|c|}
\hline № пробы & 3087 & 14 & 3091 & 3084 & 3081 & 3086 & 3080 & 3077 & 3083 \\
\hline Местоположение & Ст. Бельтир & Паспаул & Улаган & Тебелер & Кош-Агач & Ст. Бельтир & $\begin{array}{l}\text { Мухор- } \\
\text { Тархата }\end{array}$ & Хабаровка & Тебелер \\
\hline $\begin{array}{l}\text { Тип } \\
\text { водопункта }\end{array}$ & $\begin{array}{c}\text { Родник } \\
\text { Бельтирский }\end{array}$ & $\begin{array}{l}\text { Родник Па- } \\
\text { спаульский }\end{array}$ & $\begin{array}{c}\text { Родник } \\
\text { Кок-Томон }\end{array}$ & $\begin{array}{c}\text { Родник } \\
\text { Караташ }\end{array}$ & Скважина & Скважина & Скважина & $\begin{array}{l}\text { Родник Иль- } \\
\text { гуменьский }\end{array}$ & Скважина \\
\hline $\begin{array}{l}\text { Возраст } \\
\text { отложений }\end{array}$ & QIII & $\mathrm{C} 1$ & $01-2$ & D2 & $\mathrm{N} 1-2$ & D2 & P3-N1 & $\mathrm{C} 2$ & D2 \\
\hline Не абс., \% об. & 0.00005 & 0.00008 & 0.00010 & 0.00017 & 0.00022 & 0.00048 & 0.00065 & 0.00095 & 0.00429 \\
\hline${ }^{*} \mathrm{He}(\mathrm{Ka})$ & 10.2 & 17.6 & 21.8 & 36.9 & 48.1 & 105.3 & 142.2 & 207.5 & 938.6 \\
\hline $\mathrm{pH}$ & 8.4 & 7.6 & 7.6 & 9.8 & 8.2 & 8.1 & 8.2 & 7.4 & 8.1 \\
\hline $\mathrm{HCO}_{3}, \mathrm{мг} / л$ & 219.0 & 257.0 & 202.0 & 433.0 & 252.0 & 233.0 & 223.2 & 265.0 & 345.0 \\
\hline $\mathrm{Cl}, \mathrm{мг} / л$ & 8.2 & 16 & 5.7 & 306 & 45 & 26.5 & 24.2 & 8.2 & 46.7 \\
\hline $\mathrm{SO}_{4}, \mathrm{Mг} / л$ & 30.5 & 20.2 & 13.8 & 116.6 & 68.3 & 53.2 & 7.6 & 25.2 & 84.4 \\
\hline Са, мг/л & 42.4 & 66.7 & 52.1 & 90.5 & 10.3 & 41.3 & 27.4 & 60 & 50.4 \\
\hline $\mathrm{Na}$, мг/л & 8.0 & 3.4 & 8.6 & 336 & 77.1 & 27.2 & 36.6 & 19.7 & 42.3 \\
\hline $\mathrm{Mg}, \mathrm{мг/л}$ & 14 & 8.1 & 18.2 & 81.5 & 11.1 & 18.4 & 9.0 & 18.0 & 17.3 \\
\hline К, мг/л & 2.6 & 0.3 & 2.7 & 8.2 & 0.5 & 2.9 & 0.9 & 0.8 & 1.8 \\
\hline $\mathrm{SiO}_{2}$, мг/л & 3.0 & 5.5 & 5.2 & 5.7 & 6 & 3.6 & 6.4 & 9.8 & 4.9 \\
\hline Сумма, мг/л & 336 & 385 & 315 & 1387 & 478 & 415 & 344 & 414 & 601 \\
\hline
\end{tabular}

Примечание. * - Не (Ка) - контрастность превышения измеренного содержания гелия над атмосферным фоном.

Note. * - He (Ka) - contrastingly increased helium contents in the samples compared to the background helium content values in the atmosphere.

Таблица 5. Показатели химического состава родника Караташ

Table 5. Chemical composition of water sampled from the Karatash spring

\begin{tabular}{|c|c|c|c|c|}
\hline Показатели & Единицы измерения & 2004 г. & 2014 г. & 2015 г. \\
\hline $\mathrm{pH}$ & & 9.8 & 7.8 & 7.6 \\
\hline Жесткость & мг-экв/дм³ ${ }^{3}$ & 5.6 & 12.6 & 11.3 \\
\hline $\mathrm{NH}_{4}$ & \multirow{10}{*}{ мг / дм ${ }^{3}$} & 0.04 & 0.62 & 0.06 \\
\hline $\mathrm{NO}_{3}$ & & 0.005 & 6.0 & 4.3 \\
\hline $\mathrm{HCO}_{3}$ & & 366.0 & 488.0 & 488.0 \\
\hline $\mathrm{SO}_{4}$ & & 117.0 & 400.0 & 364.0 \\
\hline $\mathrm{Cl}$ & & 306.0 & 480.0 & 413.0 \\
\hline $\mathrm{Na}$ & & 264.0 & 488.0 & 337.0 \\
\hline $\mathrm{Ca}$ & & 50.0 & 83.0 & 90.0 \\
\hline Mg & & 38.0 & 140.0 & 90.0 \\
\hline Кремний & & 8.0 & 6.0 & 5.6 \\
\hline Сумма & & 1140 & 1979 & 1716 \\
\hline
\end{tabular}

пунктах РА не проводится. С учетом задачи оптимизации сети наблюдений за геофизическими и газогидрогеохимическими параметрами в Алтае-Саянском и Байкальском регионах, в первую очередь было необходимо задействовать пункты наблюдений, оснащенные средствами телеметрии, с передачей данных по каналам сотовой и спутниковой связи на сервер ФГБУ «Гидроспецгеология». Это позволит получать данные практически в реальном режиме времени и обеспечить единовременность замеров с данными наблюдений по сети ГГД мониторинга.

\section{5. ЗАКЛЮЧЕНИЕ}

Для гидрогеологических, сейсмотектонических условий Горного Алтая впервые изучено абсолютное содержание гелия в подземных водах.

Высокое содержание гелия в подземных водах связано с разломными зонами на границах тектонических 
блоков, приуроченных к эпицентральной зоне Чуйского землетрясения, максимальные значения картографируются именно в этом артезианском бассейне.

Повышенная концентрация гелия в подземных водах предполагает количественную связь между геохимическими и сейсмологическими параметрами, что представляет практический интерес для обнаружения возможного изменения деформации породного массива перед сильным землетрясением.

Полученный материал позволяет определить наиболее информативные пункты наблюдений за вариациями гелия в подземных водах Алтая. Это наблюдательные пункты ГГД мониторинга, на которых целесообразно разместить дополнительную аппаратуру, регистрирующую газовые составляющие в подземных водах, что существенно повысит достоверность прогнозов.

\section{6. ЛИТЕРАТУРА / REFERENCES}

Badminov P.S., Ivanov A.V., Pisarskij B.I., Orgil'yanov A.I., 2013. The Oka Hydrothermal System, East Sayan Mountains. Volcanology and Seismology 4, p. 27. (in Russian) [Бадминов П.С., Иванов А.В., Писарский Б.И., Оргильянов А.И. Окинская гидротермальная система (Восточный Саян) // Вулканология и сейсмология. 2013. № 4. С. 27]. https://doi.org/10.7868/S0203030613040020.

Badminov P.S., Semenov R.M., Lopatin M.N., Orgilyanov A.I., Kryukova I.G., 2017. Hydrogeochemical Studies in Pribaikalie in Connection with the Search for Earthquake Precursors. In: Geology and Mineral Resources of the NorthEastern Regions of Russia. Materials of the VII All-Russia Scientific and Practical Conference Dedicated to the 60th Anniversary of the Institute of Diamond and Precious Metal Geology SB RAS. P. 286-290 (in Russian) [Бадминов П.С., Сeменов Р.М., Лопатин М.Н., Оргильянов А.И., Крюкова И.Г. Гидрогеохимические исследования в Прибайкалье в связи с поисками предвестников землетрясений // Геология и минерально-сырьевые ресурсы северо-востока России: Материалы VII Всероссийской научно-практической конференции, посвященной 60-летию Института геологии алмаза и благородных металлов Сибирского отделения РАН. 2017. С. 286-290].

Biagi P.F., Castellana L., Minafra A., Maggipinto G., Maggipinto T., Ermini A., Molchanov O., Khatkevich Y.M., Gordeev E.I., 2006. Groundwater Chemical Anomalies Connected with the Kamchatka Earthquake (M=7.1) on March 1992. Natural Hazards Earth System Science 6, 853-859.

Bogachkin B.M., 1981. Tectonic Development History of Gorny Altai in the Cenozoic. Nauka, Moscow, 131 p. (in Russian) [Богачкин Б.М. История тектонического развития Горного Алтая в кайнозое. М.: Наука, 1981. 131 с.].

Chen C.-H., Wang S., Wen S., Yeh T.-K., Lin C.-H., Liu J.-Y., Yen H.-Y., Lin T.-W., 2013. Anomalous Frequency Characteristics of Groundwater Level before Major Earthquakes in Taiwan. Hydrology and Earth System Sciences 17 (5), 16931703. https://doi.org/10.5194/hess-17-1693-2013.

Dutova E.M., 2000. Features of the Formation of the Hydrogeochemical Background of Scattered Elements in Humid
Climate. In: Materials of the Regional Conference. V. 1. Tomsk, p. 369-372 (in Russian) [Дутова Е.M. Особенности формирования гидрогеохимического фона рассеянных элементов в условиях гумидного климата // Материалы региональной конференции. Томск, 2000. Т. 1. С. 369-372].

Dutova E.M., 2003. High-Altitude Hydrogeochemical Zoning of the Altai-Sayan Folded Region. In: Proceedings of the All-Russia Conference. Problems of Exploration and Environmental Geochemistry of Siberia. Tomsk, p. 65-69 (in Russian] [Дутова Е.M. Высотная гидрогеохимическая зональность Алтае-Саянской складчатой области // Проблемы поисковой и экологической геохимии Сибири: Труды Всероссийской конференции. Томск, 2003. C. 65-69].

Dutova E.M., 2005. Hydrogeochemistry of the Hypergenesis Zone of the Altai-Sayan Folded Region. Brief PhD Thesis (Doctor of Geology and Mineralogy). Tomsk, 46 p. (in Russian) [Дутова Е.М. Гидрогеохимия зоны гипергенеза Алтае-Саянской складчатой области: Автореф. дис ... докт. геол.-мин. наук. Томск, 2005. 46 с.].

Dutova E.M., Bukaty M.B., Nevol'ko A.I., Pokrovsky D.S., Shvartsev S.L., 2006. Hydrogenic Concentration of Gold in Alluvial Placers of the Egor'evsk Area (Salair). Geology and Geophysics 47 (3), 364-376.

Dutova E.M., Nikitenkov A.N., Pokrovskiy V.D., Banks D., Frengstad B.S., Parnachev V.P., 2017. Modelling of the Dissolution and Reprecipitation of Uranium under Oxidising Conditions in the Zone of Shallow Groundwater Circulation. Journal of Environmental Radioactivity 178-179, 63-76. https://doi.org/10.1016/j.jenvrad.2017.07.016.

Dutova E.M., Pokrovskij D.S., Parnačev V.P., Pokrovskij V.D., 2015. Geochemical Features of Underground Water for Drinking Purposes in the Republic of Khakassia. Bulletin of Tomsk State University 394, 239-249 (in Russian) [Дутова E.M., Покровский Д.С., Парначев В.П., Покровский В.Д. Геохимические особенности подземных вод хозяйственнопитьевого назначения Республики Хакасия // Вестник Томского государственного университета. 2015. № 394. С. 239-249].

Eremeev A.N. (Ed.), 1991. Methodical Recommendations for Routine Monitoring of the Helium Content in Fluids during Geodynamic Studies and Identification of Earthquake Precursors. VIMS, Moscow, 50 p. (in Russian) [Методические рекомендации по режимным наблюдениям за содержанием гелия во флюидах при геодинамических исследованиях и выявлении предвестников землетрясений / Ред. А.Н. Еремеев. М.: ВИМС, 1991. 50 с.].

Fidani C., Balderer W., Leuenberger F., 2017. The Possible Influences of the 2012 Modena Earthquakes on the Fluorescence Spectra of Bottled Mineral Water. Hydrology Current Research 8 (3), 288. https://doi.org/10.4172/21 57-7587.1000288.

Gol'din S.V., Seleznev V.S., Emanov A.F., Filina A.G., Emanov A.A. et al., 2004. Chuya earthquake and its aftershocks. Reports of the Academy of Sciences 395 (4), 1-4 (in Russian) [Гольдин С.В., Селезнев В.С., Еманов А.Ф., Филина А.Г., Еманов А.А. и др. Чуйское землетрясение и его афтершоки // Доклады АН. 2004. Т. 395. № 4. С. 1-4]. 
Kats V.E., Drachev S.S., Obukhov I.P., Pushkareva A.M., 2009. Radon in Groundwaters of the Altai Republic during the Period of Active Seismicity in the Altai-Sayan Region. In: Regional Problems of Water Quality and Health of the Population. Lipetsk, p. 45-49 (in Russian) [Кац В.Е., Драчев С.С., Обухов И.П., Пушкарева А.М. Радон в подземных водах Республики Алтай в период сейсмической активизации Алтае-Саянского региона // Региональные проблемы качества воды и здоровья населения. Липецк, 2009. С. 45-49].

Kats V.E., Shitov A.V., Drachev S.S., 2010. On the Mechanisms of Changing the Chemical Composition and Temperature of Groundwater in the Gorno-Altaisk Region. Geoecology. Engineering Geology, Hydrogeology, Geocryology 3, 207-212 (in Russian) [Кац B.Е., Шитов А.В., Драчев С.С. O механизмах изменения химического состава и температуры подземных вод в районе Горно-Алтайска // Геоэкология. Инженерная геология, гидрогеология, геокриология. 2010. № 3. С. 207-212].

Kissin I.G., 1982. The Earthquake and the Underground Water. Nauka, Moscow, 176 p. (in Russian) [Киссин И.Г. Землетрясение и подземные воды. М.: Наука, 1982. 176 c.]

Kissin I.G., 2009. Fluids in the Earth's Crust: Geophysical and Tectonical Aspects. Nauka, Moscow, 329 p. (in Russian) [Киссин И.Г. Флюиды в земной коре: геофизический и тектонический аспекты. М.: Наука, 2009. 329 с.].

Kopylova G.N., Voropaev P.V., 2005. Response of a Regime Source to an Earthquake as an Indicator of the State of Its Underground Aquifer System. Volcanology and Seismology 2, 32-44. (in Russian) [Копылова Г.Н., Воропаев П.В. Отклик режимного источника на землетрясение как индикатор состояния его подземной водоносной системы // Вулканология и сейсмология. 2005. № 2. С. 32-44].

Lopatin M.N., Semenov R.M., 2018. Variations of Dissolved Helium and Radon Caused by Earthquakes in Groundwater of the Southern Cis-Baikal Region. Doklady Earth Sciences 481 (2). C. 1037-1039. https://doi.org/10.1134/S10 $28334 X 18080160$.

Rychkova K.M., Kal'naya O.I., Ayunova O.D., 2017. Studies of Gas-Geochemical Indicators of Seismic Activity (Central Tuva, Lake Dus-Khol). Achievements of Modern Natural Sciences 12, 241-245 (in Russian) [Рычкова К.М., Кальная О.И., Аюнова О.Д. Исследования газогеохимических индикаторов сейсмической активности (Центральная Тува, оз. Дус-холь) // Успехи современного естествознания. 2017. № 12. C. 241-245].

Sano Y., Takahata N., Kagoshima T., Shibata T., Onoue T., Zhao D., 2016. Groundwater Helium Anomaly Reflects Strain Change during the 2016 Kumamoto Earthquake in Southwest Japan. Scientific Reports 6, 37939. https://doi.org/10. 1038/srep37939.

Semenov R.M., Imaev V.S., Smekalin O.P., Chipizubov A.V., Orgil'yanov A.I., 2010. Helium in the Deep Water of Lake Baikal - a Harbinger of Earthquakes. Reports of the Academy of Sciences 432 (4), 533-536 (in Russian) [Семенов Р.М., Имаев В.С., Смекалин О.П., Чипизубов А.В., Оргильянов А.И. Гелий в глубинной воде Байкала - предвестник землетрясений // Доклады АН. 2010. Т. 432. № 4. C. 533-536].

Semenov R.M., Badminov P.S., Lopatin M.N., Orgil'yanov A.I., Kryukova I.G., 2015. Hydrogeochemical Studies in the Southern Baikal Region in Connection with the Search for Earthquake Precursors. Bulletin of the Irkutsk State Technical University 2 (97), 94-98 (in Russian) [Семенов P.M., Бадминов П.С., Лопатин М.Н., Оргильянов А.И., Крюкова И.Г. Гидрогеохимические исследования в Южном Прибайкалье в связи с поисками предвестников землетрясений // Вестник Иркутского государственного технического университета. 2015. № 2 (97). С. 94-98].

Semenov R.M., Kashkovskii V.V., Lopatin M.N., 2017. Hydrogeochemical Earthquake Precursor in the Southern Baikal Region. Russian Geology and Geophysics 58 (12), 1553-1560. https://doi.org/10.1016/j.rgg.2017.11.015.

Semenov R.M., Kashkovsky V.V., Lopatin M.N., 2018. Model of Tectonic Earthquake Preparation and Occurrence and Its Precursors in Conditions of Crustal Stretching. Geodynamics \& Tectonophysics 9 (1), 165-175 (in Russian) [Семенов Р.М., Кашковский В.В., Лопатин М.Н. Модель подготовки и реализации тектонического землетрясения и его предвестников в условиях растяжения земной коры // Геодинамика и тектонофизика. 2018. Т. 9. № 1. C. 165-175]. https://doi.org/10.5800/GT-2018-91-0343.

Seminsky K.Z., Seminsky A.K., 2016. Radon in Groundwaters in the Baikal Region and Transbaikalia: Variations in Space and Time. Geodynamics \& Tectonophysics 7 (3), 477-493 (in Russian) [Семинский К.Ж., Семинский А.К. Радон в подземных водах Прибайкалья и Забайкалья: пространственно-временные вариации // Геодинамика и тектонофизика. 2016. Т. 7. № 3. С. 477-493]. https:// doi.org/10.5800/GT-2016-7-3-0218.

Seminsky K.Z., Tugarina M.A., 2011. Underground Hydrosphere in the Western Shoulder of the Baikal Rift: Results of Hydrogeological Research in the Bayandai Settlement - Krestovskii Cape Profile // Doklady Earth Sciences 439 (2), 1079-1083. https://doi.org/10.1134/S1028334X 11080289.

Shitov A.V., Kats V.E., Dutova E.M., Molokov V.Y., Pokrovskiy V.D., 2016. Changes of Chemical Groundwater Composition in the Republic of Altai due to the Earthquakes. Bulletin of the Tomsk Polytechnic University, Geo Assets Engineering 327 (1), 19-29 (in Russian) [Шитов А.В., Кац В.Е., Дутова Е.М., Молоков В.А., Покровский В.Д. Изменение химического состава подземных вод Республики Алтай при землетрясениях // Известия Томского политехнического университета. 2016. Т. 327. № 1. С. 19-29].

Shitov A.V., Kats V.E., Kharkina M.A., 2008. Ecogeodynamical assessment of the Chuya earthquake. Bulletin of Moscow University. Series 4. Geology 3, 41-47 (in Russian) [Шитов A.B., Кац В.Е., Харькина М.А. Эколого-геодинамическая оценка Чуйского землетрясения // Вестник Московского университета. Сер. 4. Геология. 2008. № 3. С. 41-47].

Shvartsev S.L., 1998. Hydrogeochemistry of Hypergenesis Zone. Nedra, Moscow, 431 p. (in Russian) [Шварцев С.Л. Гидрогеохимия зоны гипергенеза. М.: Недра, 1998. 431 с.]. 
Shvartsev S.L., Dutova E.M., 2001. Hydrochemistry and Mobilization of Gold in the Hypergenesis Zone (Kuznetsk Alatau, Russia). Geology of Ore Deposits 43 (3), 224-233.

Turkin Yu.A., Fedak S.I., 2008. Geology and StructuralMaterial Complexes of the Altai Mountains. STT, Tomsk, 460 p. (in Russian) [Туркин Ю.А., Федак С.И. Геология и структурно-вещественные комплексы Горного Алтая. Томск: STT, 2008. 459 с.].

Utkin V.I., Yurkov A.K., 1997. Radon and the Problem of Tectonic Earthquakes. Volcanology and Seismology 4, 8492 (in Russian) [Уткин В.И., Юрков А.К. Радон и проблема тектонических землетрясений // Вулканология и сейсмология. 1997. № 4. С. 84-92].

Vartanyan G.S., 1979. Earthquake Prediction Method. Russian Patent № 791021 (in Russian) [Вартанян Г.С. Способ прогнозирования землетрясений. Российский патент № 791021.1979].

Vartanyan G.S., 2019. The Global Endodrainage System: Some Fluid-Physical Mechanisms of Geodynamic Processes. Geodynamics \& Tectonophysics 10 (1), 53-78 (in Russian) [Вартанян Г.С. Глобальная эндодренажная система: некоторые флюидофизические механизмы геодинамических процессов // Геодинамика и тектонофизика. 2014. Т. 10. № 1. C. 53-78. https://doi.org/10.5800/GT-2019-10-1-0404.

Wang C-Y., Manga M., 2010. Earthquakes and Water. Springer-Verlag, Berlin and Heidelberg 114, 225 p. https:// doi.org/10.1007/978-3-642-00810-8.

Yanitskij I.N., 1979. Helium Shooting. Nedra, Moscow, 96 p. (in Russian) [Яницкий И.Н. Гелиевая съемка. М.: Недра, 1979. 96 с.]. 